\title{
Warm Mix Asphalt (WMA) for Rapid Construction in Airfield Pavement
}

\author{
Taqia Rahman ${ }^{\mathrm{a}, *}$, Andrew Dawson ${ }^{\mathrm{b}}$, Nicholas Thom ${ }^{\mathrm{c}}$ \\ a Lecturer, Department of Civil and Environmental Engineering, Universitas Gadjah Mada, Jl. Grafika No. 2, Kampus UGM, Yogyakarta 55281, Indonesia. \\ ${ }^{\mathrm{b}}$ Associate Professor, Nottingham Transportation Engineering Centre (NTEC), University of Nottingham, Nottingham, United Kingdom \\ ${ }^{c}$ Assistant Professor, Nottingham Transportation Engineering Centre (NTEC), University of Nottingham, Nottingham, United Kingdom
}

\begin{abstract}
Warm-mix asphalt (WMA) is commonly mixed and compacted $15^{\circ} \mathrm{C}$ to $30^{\circ} \mathrm{C}$ below that of conventional hot mix asphalt (HMA). The lower production temperature of WMA is expected to give an advantage of a lower cooling time of newly laid asphalt overlay before it can be opened to traffic during the nighttime airfield pavement construction. The reduced cooling time of WMA would allow shorter airport closure time window and/or extend the time for the contractor for paving, and thus shorten the overall construction period due to more volume done each night. This is a beneficial practical advantage to hectic airports where the typical off-peak period is as short as 6-8 hours. In this research, two different WMA technologies, Sasobit ${ }^{\circledast}$ and Rediset ${ }^{\circledast}$ (organic and chemical) were investigated through laboratory tests to see if there were notable differences in WMA rutting performance that could have considerable practical effects on the permissible temperature at the opening to traffic as compared to the HMA. Furthermore, a validated finite element (FE) solution for one-dimensional transient heat-transfer model is used to simulate the effect of the use of warm mix on shortening the cooling time and the overall project time. The laboratory test shows that the WMA with Sasobit has a significantly better rutting performance at the elevated temperature, enabling the WMA to be opened to traffic at a higher temperature, compared to HMA. The cooling analysis showed that, in comparison to HMA, the use of WMA could shorten the closure time of airport during the night time construction by 8-67 minutes, depending on the asphalt overlay thickness, traffic opening temperature and WMA production temperature. The use of WMA could also minimize the overall construction period by 2-16 nights for a single lift overlay, for the cases studied.
\end{abstract}

Keywords: Warm mix asphalt (WMA), Rapid construction, Rehabilitation, Airport pavements, Sasobit

\section{Introduction}

The increase of scheduled commercial flights at busy civil airports have made it imperative that airfield pavement rehabilitation and asphalt overlay be performed without disrupting airport operations. For this purpose, the off-peak period (nighttime) construction has become one practical solution for airport authorities. Using this approach, the airfield facilities are closed at night for a few hours when the flight volume is at the lowest, and then quickly opened to air traffic in the next morning. During this closed period, aircraft will use other runway facilities, if parallel runways are available, or airport operation will be postponed.

Time is the essence of the construction during the off-peak time. The typical unoccupied time of airfield pavement rehabilitation is as short as 6-8 hours per night. It is a period from 23:00 to 6:00 that was specified for runway overlay in Fukuoka airport [1]. The similar nighttime construction period can also be found in these following airport projects: San Diego International airport in 1980 (8 hours) [2], Frankfurt airport, Germany, in 2005 (8 hours) [3] and Hong Kong airport in 2006 (8 hours) [4]. However, with the increase of 24-hour airport 
operation, the period for nighttime construction has become limited. The decrease was observed in the largest Australian airports [5], where the available nighttime construction was generally reduced from eight hours in 2005 to five hours in 2015 . Rapid construction is expected to reduce the disruption due to the airport closure and allow more time for contractors to produce the maximum volume of asphalt each night to achieve satisfactorily constructed pavement.

One of the approaches for rapid nighttime construction is to shorten the cooling time of freshly paved asphalt overlay. In this case, with its advantage of lower production and compaction temperature, warm mix asphalt (WMA) gives an advantage of a lower cooling time of asphalt; thus, the pavement can be quickly opened to traffic. In the situation where the closure of the runway is substantially critical, the use of WMA is expected to shorten the runway closure time each night. In addition, in the case that the closure hours are fixed for each night, the use of WMA would enable more volume of asphalt to be laid each night, increase the target length of pavement to be done each night, thus, shortening the overall project time, compared to HMA.

The use of WMA technology for airport pavements has been few until now. The technology has more popularly been adopted for road pavement projects than airfield pavements. However, extensive research has been carried out in the last few years on the use of WMA for airside applications. Recent evidence suggests the suitability of using WMA for airfield pavement [3,6-8] Although considerable researches have been done, there has been no detailed investigation into the advantages of the use of WMA on shortening the construction time of pavement.

The present study was performed to investigate the benefit of WMA over HMA pavements in terms of the rapid construction of airport. The rutting performance of WMA and HMA at higher temperatures was evaluated. Furthermore, a cooling simulation of new asphalt is developed to analyse the effect of the use of warm mix on shortening the overall project time.

\section{Research Objective and Approach}

The main purpose of this study is to investigate the advantage of using WMA for rapid asphalt overlay in civil airports. The rutting performance of WMA and HMA at higher temperature was also evaluated. Two different WMA technologies: organic wax and chemical were investigated through laboratory tests to see if there were notable distinctions in WMA rutting performance that could have considerable practical effects on the permissible temperature at the opening to traffic as compared to the HMA. It is hypothesized that with the reduced viscosity of WMA, the WMA could have more potential to rut, and thus the WMA should be opened to traffic at lower temperatures, compared to HMA.

Furthermore, to evaluate the effect of the use of WMA on the reduction of airfield closure during the nighttime construction, a finite element (FE) solution for one-dimensional transient heat-transfer model is established. Actual field measurement data from a previous study was used to validate the model. Different asphalt overlay thicknesses and production temperatures of WMA were analysed to investigate the advantage of WMA, if any, in shortening the airport closure time due to its quicker cooling time before traffic opening. Furthermore, a case study based on an airport overlay project is presented to highlight the advantage of WMA technologies have to shorten the overall project time of runway rehabilitation.

\section{Material and Testing Program}

\subsection{Materials}

\subsubsection{Asphalt Binder}

In this study, a neat 40/6o Pen grade asphalt binder and the same binder modified by styrene-butadiene-styrene (SBS) copolymer were used as controls. Penetration, viscosity, and softening point of the binders are shown in Table 1. Each of the control binders is then blended with two different WMA technology.

Table 1. Binder characterization.

\begin{tabular}{ccccc}
\hline No. & Property & Units & Neat binder & $\begin{array}{c}\text { SBS modified } \\
\text { bitumen }\end{array}$ \\
\hline 1 & Penetration $@ 25^{\circ} \mathrm{C}$ & $\mathrm{dmm}$ & 53 & $45-80$ \\
2 & Softening Point & ${ }^{\circ} \mathrm{C}$ & 50 & $>65$ \\
3 & Viscosity at $\left(135^{\circ} \mathrm{C}\right)$ & Pa.s & 0.395 & 0.960 \\
4 & Viscosity at $\left(165^{\circ} \mathrm{C}\right)$ & Pa.s & 0.114 & 0.302 \\
\hline
\end{tabular}

\subsubsection{Warm Mix Additives}

The two types of additives for WMA, organic and chemical, are respectively used: Sasobit $\AA$, one of the best organic WMA additives available, and Rediset $\AA$ LQ-1102CE, a popular chemical WMA additive. The Sasobit $\AA$ concentration was selected at the rate of $2 \%$ of asphalt binder based on past research made by Jamshidi, Hamzah [9]. The Rediset $\AA$ is added at $0.5 \%$ by weight of asphalt binder following a recommended dosage by Akzonobel $囚$. Both additives are shown in Fig. 1. The two warm-mix technologies at selected dosage rates were blended with the control asphalt binders (shown in Table 1) in the laboratory, based on British Standard BS EN 12594:2014. A total of six asphalt binders are used for the tests. The asphalt binders and mixtures designation is presented in Table 2. 
Table 2. Mixes used in this research.

\begin{tabular}{|c|c|c|c|c|c|}
\hline $\begin{array}{l}\text { Terminology } \\
\text { of mixtures }\end{array}$ & Binder type & WMA Additives & State of additives & $\begin{array}{c}\text { Additives dosage (\% of } \\
\text { binder weight) }\end{array}$ & Mixing Temperature $\left({ }^{\circ} \mathrm{C}\right)$ \\
\hline B1 & Polymer modified binder & - & - & - & 175 \\
\hline B2 & Polymer modified binder & Sasobit $^{\circledR}$ & Prill form & $2 \%$ & 155 \\
\hline B3 & Polymer modified binder & Rediset $^{\circledR}$ LQ-1102CE & Viscous liquid & $0.5 \%$ & 155 \\
\hline B4 & Pen. grade $40 / 60$ & - & - & - & 160 \\
\hline B5 & Pen. grade $40 / 60$ & Sasobit ${ }^{\circledR}$ & Prill form & $2 \%$ & 140 \\
\hline B6 & Pen. grade $40 / 60$ & Rediset $^{\circledR}$ LQ-1102CE & Viscous liquid & $0.5 \%$ & 140 \\
\hline
\end{tabular}

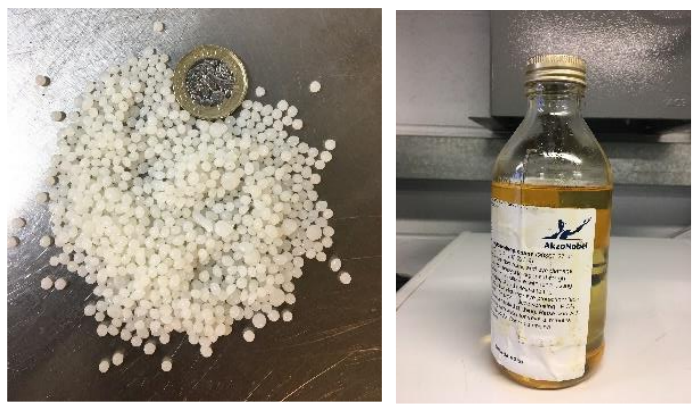

(a) Sasobit ${ }^{\circledR}$

(b) Rediset ${ }^{\circledR}$ LQ-1102CE

Fig. 1. Warm mix additives for the research.

\subsection{Asphalt Mixture Gradation}

The asphalt mixtures for the research were arranged according to FAA Item P-401, dense graded asphalt concrete [10]. The particle size distribution for the mix of aggregates is depicted in Fig. 2. The aggregate grading was conducted according to BS EN 933-1:2012. The Aggregate used in this study were from existing stockpiles of granite aggregates from Bardon Hill (Leicestershire, UK).

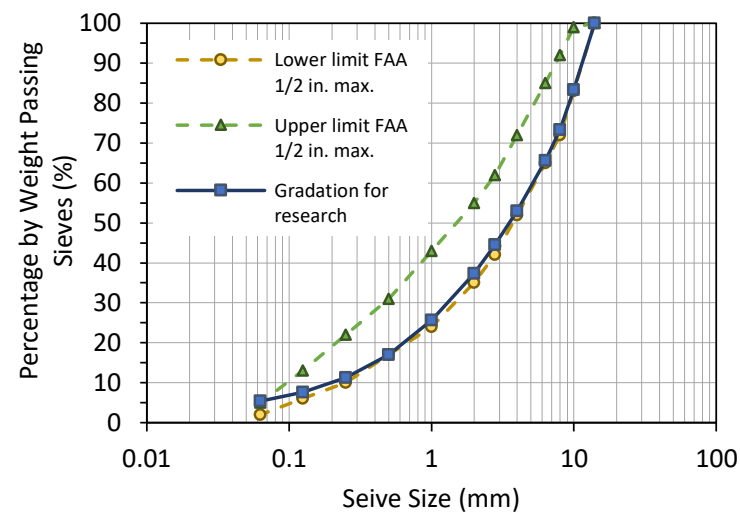

Fig. 2. Aggregate gradation with $14 \mathrm{~mm}$ max. aggregate size

\subsection{Asphalt Mixture Preparations}

Brookfield viscometry test was performed to investigate the suitable WMA reduced production temperature. It was found that, based on the viscosity-temperature relationship from the test, both warm mix additives were responsible for a reduction of only about $5^{\circ} \mathrm{C}$ in mixing temperature. The reduced production temperature of WMA based on the viscosity comparison was not as much as $15^{\circ} \mathrm{C}$ of reduction as found in Liu, Saboundjian [11] or even $25^{\circ} \mathrm{C}$ of reduction as shown by NCAT Report 05-06. The unremarkable impact on the mix temperature of Sasobit-WMA mixtures when it is determined using the viscosity test is also found in other studies: Wasiuddin, Selvamohan [12] Tasdemir [13], Silva, Oliveira [14], Jalali, Grenfell [15] and Abed, Thom [16]. Furthermore, in this research, the compaction energy index (CEI) and the traffic densification index (TDI) approach suggested by SanchezAlonso, Vega-Zamanillo [17] is used to determine the production temperatures of WMA. It was found that reducing the mixing and compaction temperature by $20^{\circ} \mathrm{C}$ would result in the same compaction workability of WMA compared to HMA. In this study, both WMA technologies were produced at $20^{\circ} \mathrm{C}$ below that of HMA.

The asphalt mixtures were manufactured using the same mixture gradation, air voids of $3.5 \%$, and asphalt content of $5.8 \%$ obtained from the Marshall mix design test. A Superpave gyratory compactor was used as the compaction machine. After compaction, the cylindrical specimens are cut (top and bottom side) into a thickness of $60 \mathrm{~mm}$ to be used as specimens for repeated load axial test (RLAT). To reach the 'high' temperature (see later), the specimens are conditioned and heated up before being tested. Six different mixes using the asphalt binders presented earlier in Table 2 were manufactured for RLAT.

\subsection{Test Methods}

\subsubsection{Multiple Stress Creep Recovery (MSCR) Test}

Many recent studies [18-20] suggest that Multiple Stress Creep Recovery (MSCR) test of binders correlates better with rutting potential of asphalt than other parameters, particularly to assess the polymer modified binder performance. In this study, MSCR tests were conducted on the 6 binders using the Dynamic Shear Rheometer (DSR). The MSCR test is performed at two stress levels ( 0.1 and $3.2 \mathrm{kPa}$ ). For each stress level, ten cycles of loading and unloading, as shown in Fig. 3, are applied. The load is applied for $1 \mathrm{~s}$, the specimen is then allowed for $9 \mathrm{~s}$ rest period. The output parameters of the test are the nonrecoverable creep compliance $\left(\mathrm{J}_{\mathrm{nr}}\right)$ and $\mathrm{MSCR} \%$ of recovery. 
The $\mathrm{J}_{\mathrm{nr}}$ measures the proportion of permanent strain of binder specimen after periodically stressed and relaxed, relative to the amount of applied stress. The MSCR \% recovery is a proportion of how much the binder sample reforms to its initial shape after being repeatedly loaded and unloaded. In this paper, the MSCR test was performed at three different test temperatures: $64^{\circ} \mathrm{C}$, $76^{\circ} \mathrm{C}$, and $82^{\circ} \mathrm{C}$.

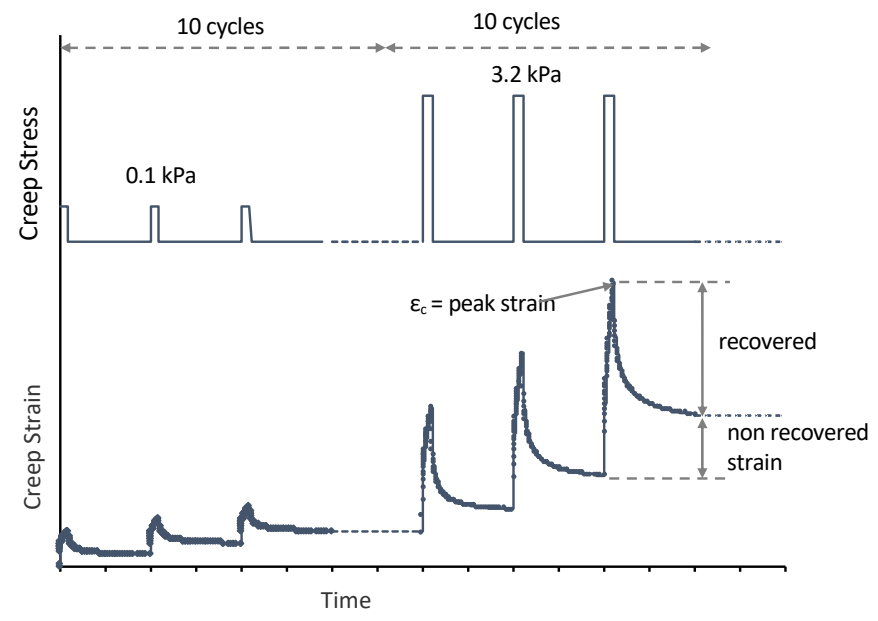

Fig. 3. Typical MSCR test results

\subsubsection{Repeated Load Axial Test (RLAT)}

The Repeated Load Axial Test (RLAT) was developed to investigate the behaviour of asphalt material under field-like loading conditions. An $8 \mathrm{kN}(1000 \mathrm{kPa})$ load is repeatedly applied for 1s of loading time, and is of rest period after each loading pulse (frequency of $0.5 \mathrm{~Hz}$ ). The RLAT was run in the temperature range of $60^{\circ} \mathrm{C}$ to $85^{\circ} \mathrm{C}$ for 2000 load cycles or until a failure occurred (10mm of deformation). The equipment used for the test is a servo-Pneumatic universal testing machine (NU14) from Cooper Technology, as shown in Fig. 4.
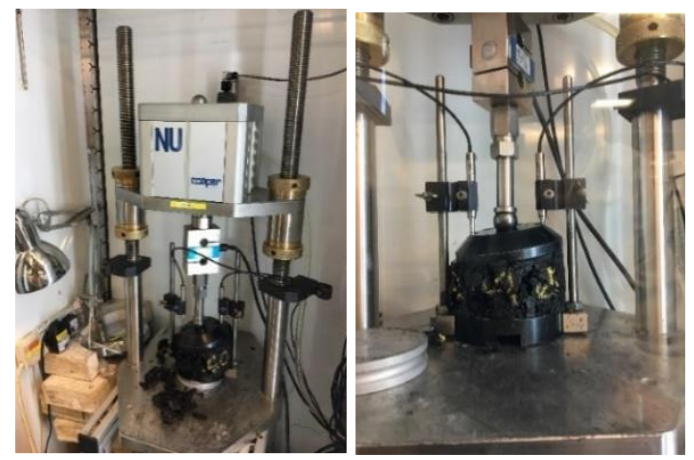

Fig. 4. RLAT setup using NU14 and deformation after the test

\section{Test Results and Discussion}

\subsection{Multiple Stress Creep Recovery (MSCR) Test}

The typical output of the MSCR tests is presented in Fig. 5 and Fig. 6 for MSCR tests at $3.2 \mathrm{kPa}$ at $76^{\circ} \mathrm{C}$ for SBS modified binders and neat binders, respectively, with the addition of WMA additives. In general, it was found that, at high temperature, the binders modified with SBS (B1, B2, B3) showed much lower accumulated strain than the unmodified binder (B4, B5, B6), indicating lower rutting potential of the mixes with a polymer-modified binder.

The addition of Sasobit $\AA$ additives to the SBS modified binder (B2), as shown in Fig. 5, improves the strain response of the unchanged binder (B1) drastically. This can be seen from the lower accumulated strains of B2 at the end of the test. A similar trend of decreased accumulated strain of binder with the addition of Sasobit@ (B5) was observed for neat binder (pen. grade 40/60), see Fig. 6.

The addition of Rediset $\AA$ additives (B3 and B6) does not significantly change the rheological behaviour of the binders. Thus the benefit of the Rediset additive appears to be in permitting lower mixing temperature but then delivering a virtually unchanged asphalt.

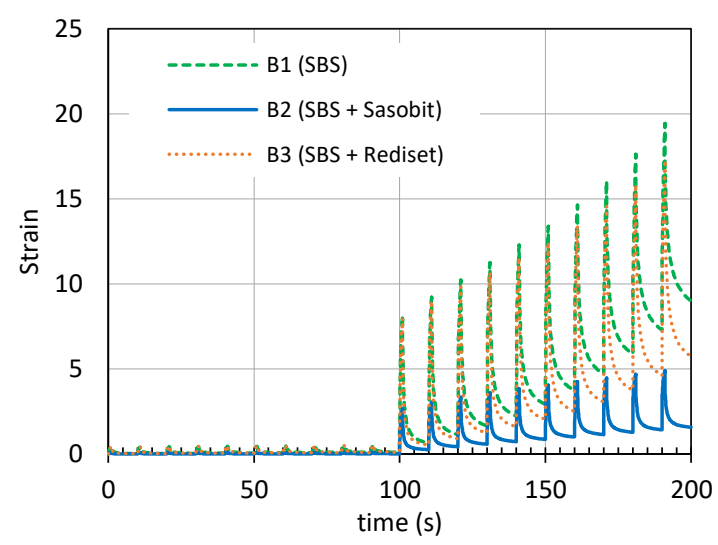

Fig. 5. MSCR tests at $76^{\circ} \mathrm{C}$ for SBS binder + WMA additives.

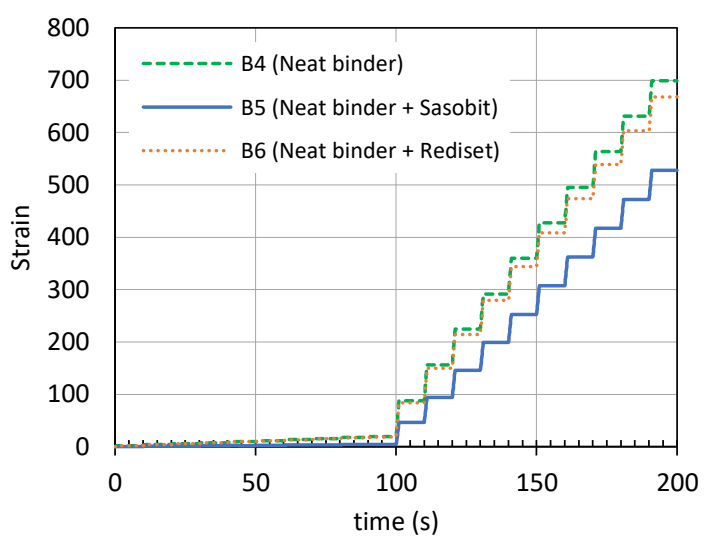

Fig. 6. MSCR tests at $76^{\circ} \mathrm{C}$ for Neat binder + WMA additive 
Table 3. MSCR test data and analysis for the binders at elevated temperature

\begin{tabular}{|c|c|c|c|c|c|c|}
\hline \multirow{2}{*}{ Binders } & \multicolumn{2}{|c|}{$64^{\circ} \mathrm{C}$} & \multicolumn{2}{|c|}{$76^{\circ} \mathrm{C}$} & \multicolumn{2}{|c|}{$82^{\circ} \mathrm{C}$} \\
\hline & $\mathrm{Jn}_{\mathrm{nr}} @ 3.2 \mathrm{kPa}\left(\mathrm{kPa}^{-1}\right)$ & $\varepsilon_{\mathrm{r}} 3.2 \mathrm{kPa}(\%)$ & $\mathrm{Jnr}_{\mathrm{nr}} @ 3.2 \mathrm{kPa}\left(\mathrm{kPa}^{-1}\right)$ & $\varepsilon_{\mathrm{r}} 3.2 \mathrm{kPa}(\%)$ & $\mathrm{Jnr}_{\mathrm{nr}} @ 3.2 \mathrm{kPa}\left(\mathrm{kPa}^{-1}\right)$ & $\varepsilon_{\mathrm{r}} 3.2 \mathrm{kPa}(\%)$ \\
\hline B1 & 0.036 & 97.75 & 0.28 & 91.59 & 4.349 & 48.3 \\
\hline B2 & 0.010 & 97.83 & 0.05 & 94.91 & 0.735 & 74.605 \\
\hline B3 & 0.041 & 97.59 & 0.18 & 94.64 & 3.390 & 60.0 \\
\hline B4 & 4.322 & 0.35 & 21.23 & -1.12 & 40.706 & -1.99 \\
\hline B5 & 2.984 & 2.24 & 16.37 & -0.80 & 37.199 & -1.99 \\
\hline B6 & 4.463 & 0.31 & 20.29 & -2.23 & 40.918 & -2.2 \\
\hline
\end{tabular}

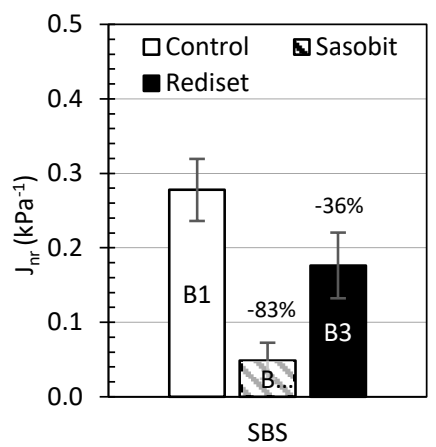

(a)

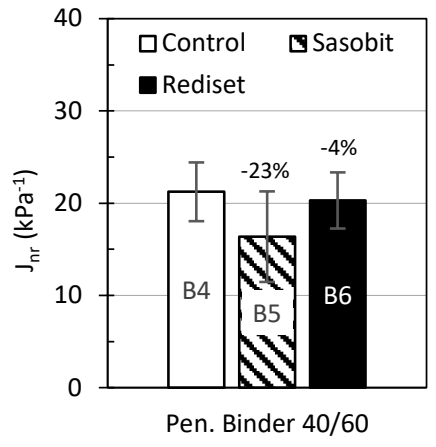

(b)

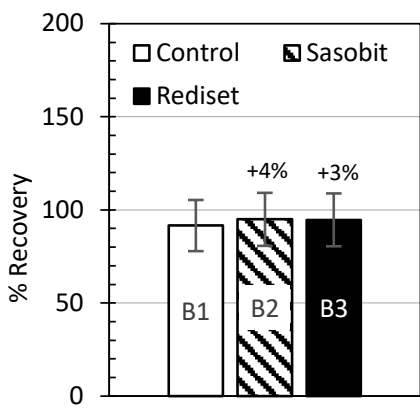

SBS

(c)

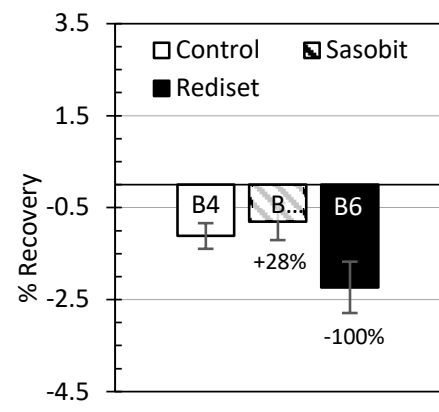

Pen. Binder 40/60

(d)

Fig. 7. Variations in creep compliance (Jnr) and percent recovery of binders at $76^{\circ} \mathrm{C}$ (unaged condition): (a) Jnr of SBS binder, (b) Jnr of neat binder, (c) \% Recovery of SBS binder and (d) \%Recovery of neat binder

As mentioned before, the outputs of the MSCR test are the non-recoverable creep compliance $\left(\mathrm{J}_{\mathrm{nr}}\right)$ and MSCR \% recovery. The $\mathrm{J}_{\mathrm{nr}}$ and \%recovery of the six binder specimens at all test temperatures $\left(64^{\circ} \mathrm{C}, 76^{\circ} \mathrm{C}\right.$, and $82^{\circ} \mathrm{C}$ ) at $3.2 \mathrm{kPa}$ stress level are presented in Table 3. Additionally, for illustration purposes, the test results for binder specimens at $76^{\circ} \mathrm{C}$ are displayed in Fig. 7. From Fig. 7, it is apparent that at the test temperature of $76^{\circ} \mathrm{C}$, the $\mathrm{Jn}_{\mathrm{nr}}$ value of binders with the addition of Sasobit (B2 and $\mathrm{B}_{5}$ ) was found to be significantly lower than that of the control binder (B1 and B4). Furthermore, a higher percentage of recovery of the $\mathrm{B} 2$ and $\mathrm{B} 5$ was observed. A similar trend can also be found at test temperatures of $64^{\circ} \mathrm{C}$ and $82^{\circ} \mathrm{C}$, as seen in Table 3. The reduction of $\mathrm{J}_{\mathrm{nr}}$ and improvement of \%Recovery of binders with the addition of Sasobit indicates a lower potential of the asphalt binder to rutting. Similar impacts of Sasobit@ supplement on lower non-recoverable compliances of binders can also be found from other researches: Morea, Marcozzi [21], Ziari and Babagoli [22], Ali, Kim [23], and Julaganti, Choudhary [24]. Additionally, in general, the binders with the addition of Rediset result in comparable $\mathrm{J}_{\mathrm{nr}}$ and \%Recovery of the control binder.

\subsection{RLAT Results}

Fig. 8 presents the permanent deformation profiles of the RLAT of the asphalt mixtures at $50^{\circ} \mathrm{C}, 60^{\circ} \mathrm{C}, 75^{\circ} \mathrm{C}$ and $85^{\circ} \mathrm{C}$. In general, the results obviously show greater permanent deformation at the higher test temperature. This was predicted, as will greater temperatures and load, the asphalt mixtures are more susceptible to plastic deformation. The specimens immediately failed after few cycles, especially at $85^{\circ} \mathrm{C}$.

In general, it is shown that the mixtures with SBS binders (B1, B2, B3) show much better rutting performance at high temperature than the conventional pen. grade 40/60 binders (B4, B5, B6). It was also observed that the WMA Sasobit showed better rut resistance than the WMA Rediset and HMA at all temperatures, while the use of chemical additives (Rediset) led to slightly higher permanent deformation. For instance, as summarized in Table 4 , at $85^{\circ} \mathrm{C}$, the RLAT cycles to failure of mixtures with SBS control binder (B1) were 90 cycles. The cycles to failure for mixtures with the addition of warm mix additives, B2 (Sasobit) and B3 (Rediset), were 176 and 79, respectively. Comparatively, the RLAT cycles to failure at $85^{\circ} \mathrm{C}$ for mixtures with pen. grade $40 / 60$ control binder (B4) are only 4 cycles. At the same temperature, the RLAT cycles to failure were 43 cycles for mixtures with B5 (Sasobit) and 26 cycles for B6 (Rediset).

\subsection{RLAT Results vs. MSCR results}

Table 4, Fig. 9 and Fig. 10 and shows a plot of the RLAT against the $\mathrm{J}_{\mathrm{nr}}$ (non-recoverable compliance) from the MSCR test at the high test temperature, for SBS binders and pen. grade 40/6o binders, respectively. A linear relationship of the MSCR test results of neat binders to RLAT permanent deformation provided a good relationship with an $\mathrm{R}^{2}$ of 0.913 (Fig. 10). 
RLAT @ 85ㄷ

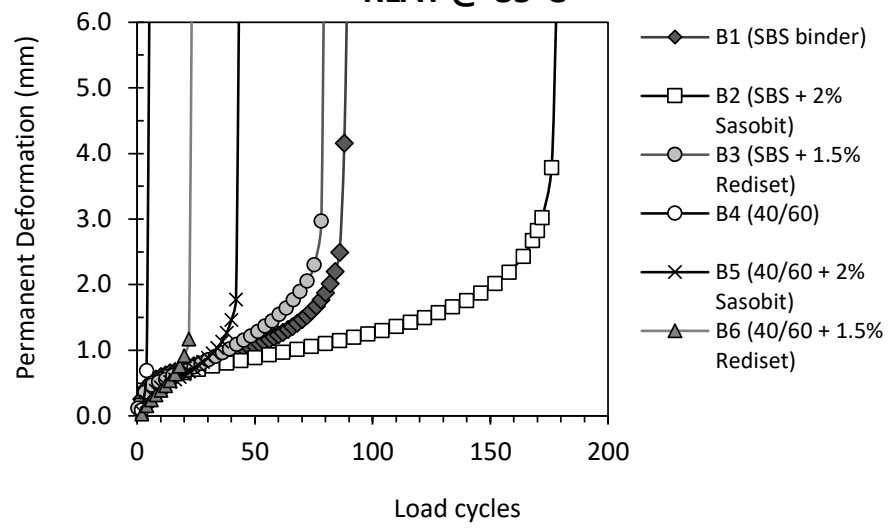

(a) Test temperature: $85^{\circ} \mathrm{C}$

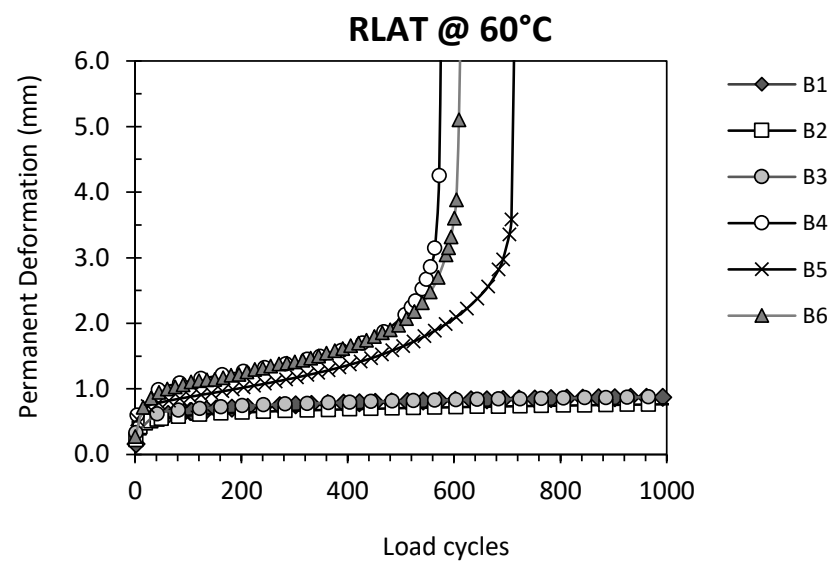

(c) Test temperature: $60^{\circ} \mathrm{C}$

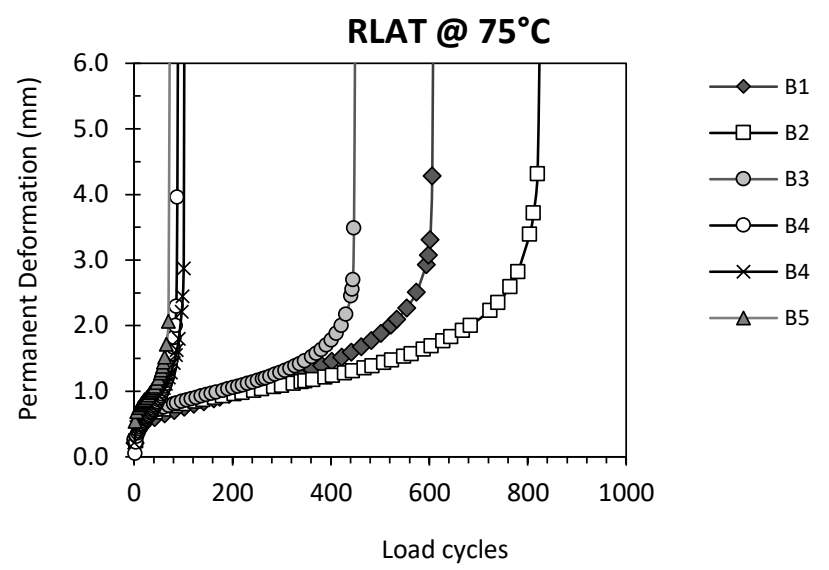

(b) Test temperature: $75^{\circ} \mathrm{C}$

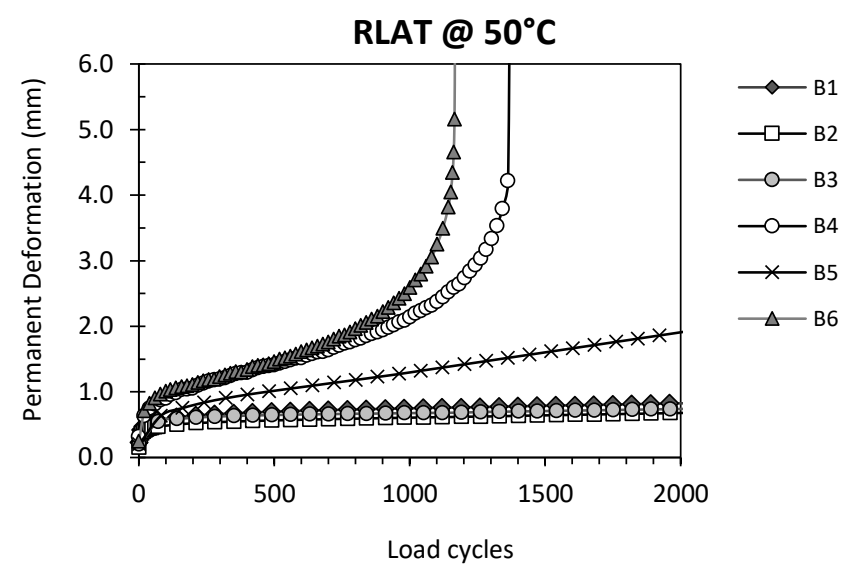

(d) Test temperature: $50^{\circ} \mathrm{C}$

Fig. 8. RLAT results

Additionally, for SBS modified binders, a power-law relationship provided a better correlation of $\mathrm{J}_{\mathrm{nr}}$ to permanent deformation with an $\mathrm{R}^{2}$ of 0.929 . Considering the mix variability from sample preparation, the $\mathrm{J}_{\mathrm{nr}}$ of MSCR correlates very well with the asphalt mixture permanent deformation assessed by the RLAT.

Table 4. Test temperature, RLAT cycles to failure of mixtures and MSCR binder properties of asphalt binder

\begin{tabular}{cccc}
\hline $\begin{array}{c}\text { Binder/mix } \\
\text { with binder: }\end{array}$ & Test temp. $\left(^{\circ}\right)$ & $\begin{array}{c}\text { RLAT cycles to } \\
\text { failure }\end{array}$ & $\begin{array}{c}\text { MSCR } \\
\mathrm{Jr}_{\mathrm{nr}} \text { at } 3.2 \mathrm{kPa}^{-1}\end{array}$ \\
\hline B1 & 75 & 609 & 0.28 \\
& 85 & 90 & 4.35 \\
B2 & 75 & 824 & 0.05 \\
& 85 & 176 & 0.74 \\
B3 & 75 & 448 & 0.18 \\
& 85 & 79 & 3.39 \\
B4 & 75 & 90 & 21.23 \\
& 85 & 4 & 40.71 \\
B5 & 75 & 103 & 16.37 \\
& 85 & 43 & 37.20 \\
B6 & 75 & 74 & 20.29 \\
& 85 & 26 & 40.92 \\
\hline
\end{tabular}

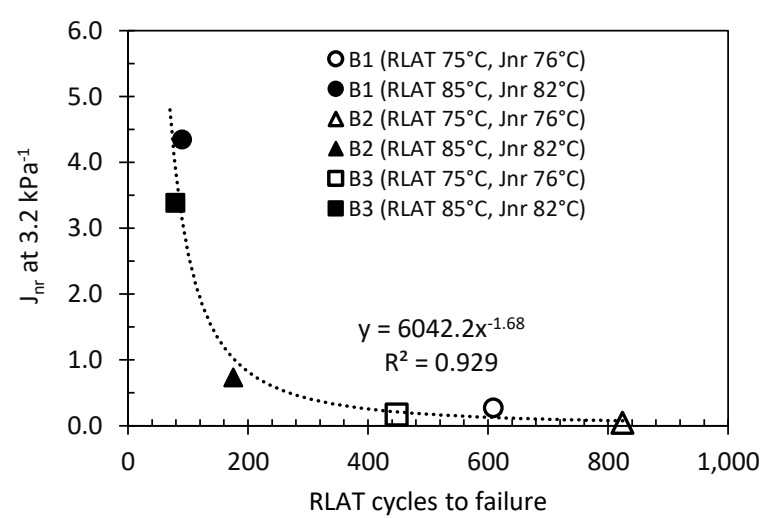

Fig. 9. Relationship of Jnr at $3.2 \mathrm{kPa}-1$ and RLAT results for SBS modified binders with and without warm mix additives at elevated temperature (B1,B2,B3)

Based on the binder test (MSCR) and RLAT, the rutting performance of WMA is comparable with the HMA. Interestingly, the addition of Sasobit to control binders improved significantly the rutting resistance of asphalt at fairly 
high temperature. This is likely, because based on the Brookfield viscometry test results displayed in Fig. 11, after the asphalt temperature drops to the Sasobit's wax transition temperature $\left(95-115^{\circ} \mathrm{C}\right)$, the Sasobit begins to harden and increases the viscosity. The results indicate that the addition of Sasobit would enable the new asphalts to be opened to traffic at higher temperatures than HMA or WMA with added Rediset.

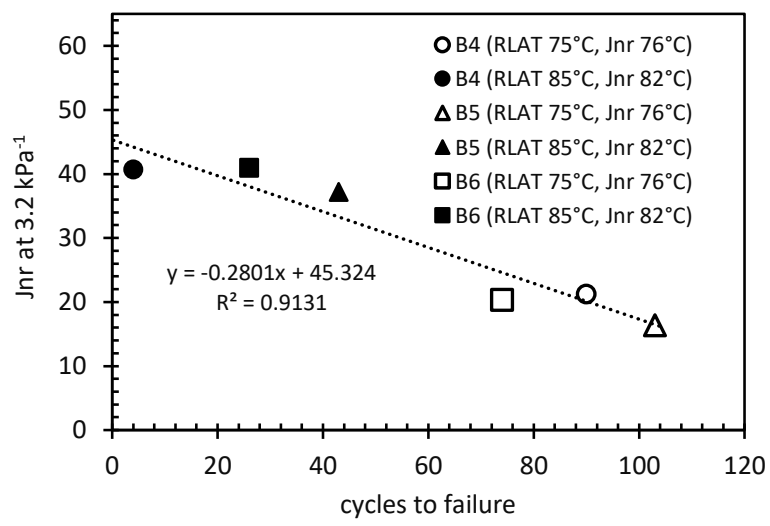

Fig. 10. Relationship of Jnr at $3.2 \mathrm{kPa}-1$ and RLAT results for neat binders with and without warm mix additives at elevated temperature $(\mathrm{B} 4, \mathrm{~B} 5, \mathrm{~B} 6)$

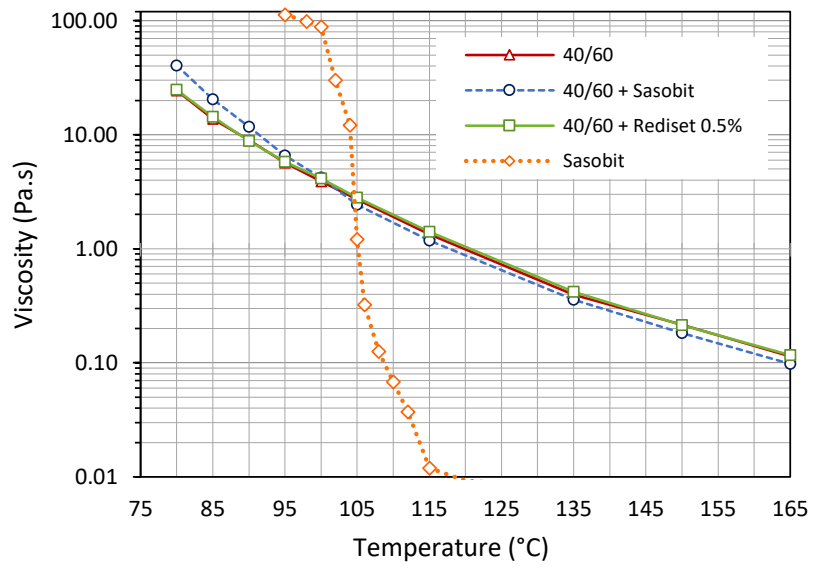

Fig. 11. Brookfield viscometer test results

The following findings may be carried out from the MSCR and RLAT results:

- The laboratory test results showed that WMA has a rutting performance similar to, or better than HMA.

- Rediset LQ chemical additive has nearly no effect on the rheological of the binder and rutting performance of asphalt mixture. Its principal action is to allow mixing at lower temperatures.

- The addition of Sasobit additive improved the rutting resistance of asphalt binder and mixture significantly. This can be seen from the lower Jnr and higher \%Recovery of
MSCRs test and a greater number of cycles to failure in the RLAT at high temperature.

- Reduction in viscosity at the production temperature by adding Sasobit did not increase rut depth at the temperature at the opening to traffic $\left(60-85^{\circ} \mathrm{C}\right)$. Rather, the addition of the Sasobit additive improved the stiffness and rutting resistance of asphalt mixture.

- In terms of the allowable temperature of opening to traffic, with the excellent rutting performance of WMA of Sasobit, the use of WMA could give an advantage of opening the asphalt at a higher temperature than HMA, and thus shortening the lag time of asphalt cooling.

- The permanent deformations correlate well with the nonrecoverable creep compliances $\left(\mathrm{J}_{\mathrm{nr}}\right)$ from the MSCR test $\left(\mathrm{R}^{2}=0.91-0.93\right)$.

\subsection{Comparison of HMA and WMA Cooling and Construction Time}

In this section, the effect of the use of WMA on construction time is investigated for two conditions: (1) to reduce closure time each night, when the airfield is required to be opened quickly; and (2) to shorten the overall construction period, when the runway closure time is fixed each night. Three different asphalt mixtures are reviewed: one HMA and two WMAs for different temperature reduction. The temperature for HMA spreading was assumed to be $145^{\circ} \mathrm{C}$, in contrast, it is considered $125^{\circ} \mathrm{C}$ (WMA-20) and $115^{\circ} \mathrm{C}$ (WMA-3o) for WMA.

\subsubsection{Heat transfer model of asphalt cooling}

In this research, a one-dimensional thermal transient model of asphalt pavement using ABAQUS, developed from a previous study (Rahman, Thom [25]), is adopted. The finite element model (FEM) is selected because it is versatile in predicting both surface and inner pavement temperatures. The model also allows for a wide variety of climatic conditions and thermophysical properties of the paving material. The use of FEM has been successfully used in many studies [26-28] in predicting the cooling of newly laid asphalt.

For the purpose of this research, a typical pavement structure commonly used at airfield is simulated by 4-node quadrilateral elements, DC2D4 (heat transfer). The pavement structure consists of asphalt overlay, existing dense-graded asphalt course, unbound base layer, and subgrade, as presented in Fig. 12. The solar and infrared radiation, heat transfer convection at the pavement surface, and heat conduction into the underneath layers are considered. The right and left boundaries were assumed to be thermally isolated, whereas, the bottom boundary was assumed to be a constant temperature; since it was far from the new asphalt overlay. The typical output 
of the heat transfer model, showing the pavement temperature distribution at 49 mins after placing, is illustrated in Fig. 13

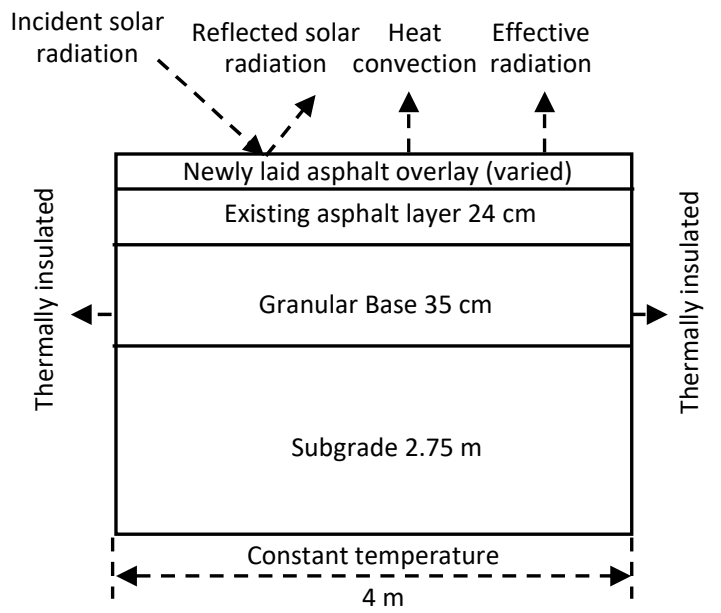

Fig. 12. Layout of airfield pavement structure for cooling analysis.

\subsubsection{Model Validation}

To validate the accuracy of the model, the heat transfer model was validated against site measurement, compiled from four projects in Minnesota, USA, by Chadbourn, Newcomb [29] between 1996 and 1997. The paving conditions of the projects are shown in Table 5.

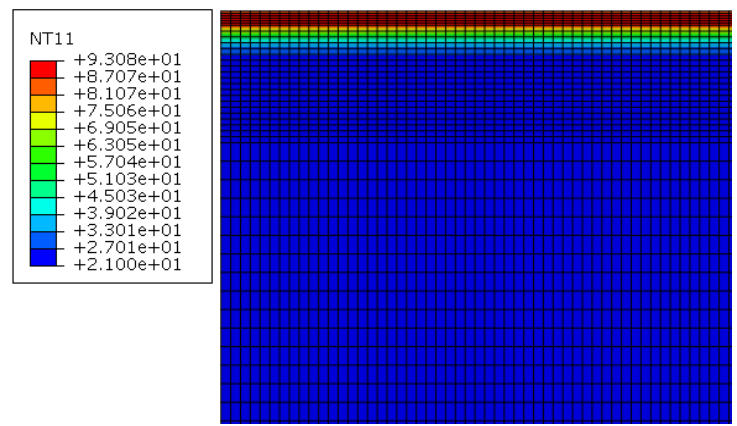

Fig. 13. Typical output of the FE heat transfer model

Using the paving condition data in Table 5, analyses were performed to confirm the accuracy of the heat transfer model. The comparisons of the heat transfer model and field data are displayed in Fig. 14 for temperatures at middle points of asphalt overlay. The results show a good agreement between the developed heat transfer model and site cooling measurements, confirming the suitability of the developed model.

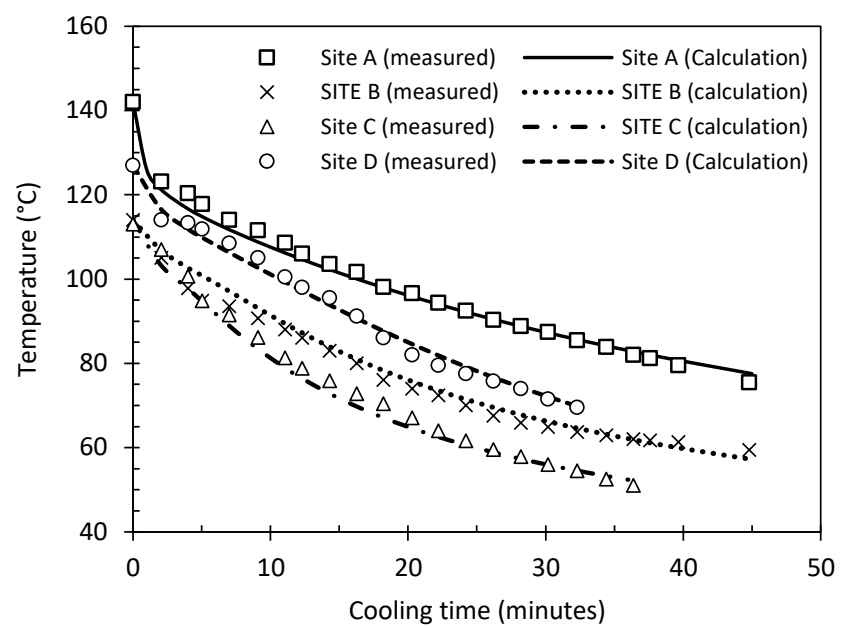

Fig. 14. Comparison of cooling prediction and in-situ measurement of new asphalt overlay at mid-depth of layer

To examine the heat transfer model results more objectively, the root-mean-square error (RSME) of the model was used as the objective parameter [27]:

$$
R M S E=\sqrt{\frac{1}{n} \sum_{i=1}^{n}\left(T_{i, \text { measured }}-T_{i, \text { calculated }}\right)^{2}}
$$

where $T_{i, \text { measured }}$ is the measured temperature at a specific time point $\mathrm{i}, T_{i, \text { calculated }}$ is the calculated temperature at the same time point and $n$ is the number of data.

A summary of the RMSE assessment results is presented in Table 6. It can be seen that the differences between the measured and predicted temperatures are sensibly small, suggesting a general correspondence between the field measurement and prediction. Therefore, the heat transfer model is feasible for further analysis of the cooling time of newly laid asphalt pavement.

Table 5. Cooling parameters of in-situ asphalt pavement measurement (Chadbourn, Newcomb [29])

\begin{tabular}{|c|c|c|c|c|c|c|c|}
\hline \multirow[b]{2}{*}{ Site } & \multicolumn{7}{|c|}{ Cooling Parameters } \\
\hline & Location & Date and time & Wind speed & $\begin{array}{c}\text { Existing surface type and } \\
\text { temp. }\end{array}$ & Air temp. & $\begin{array}{l}\text { Lift } \\
\text { thickness }\end{array}$ & Cloud cover \\
\hline$A$ & Highway 52. Rosemount, MN & 12 July 1996, 9:45 am & $4.44 \mathrm{~m} / \mathrm{s}$ & $\operatorname{HMA}\left(22.7^{\circ} \mathrm{C}\right)$ & $19.4^{\circ} \mathrm{C}$ & $64 \mathrm{~mm}$ & $50 \%$ \\
\hline B & Ipava Avenue, Lakeville, MN & 13 Oct. $1995,10: 30 \mathrm{am}$ & $4.44 \mathrm{~m} / \mathrm{s}$ & Aggregate base $\left(19.4^{\circ} \mathrm{C}\right)$ & $16.4^{\circ} \mathrm{C}$ & $50 \mathrm{~mm}$ & $0 \%$ \\
\hline $\mathrm{C}$ & Ipava Avenue, Lakeville, MN & 14 Oct. $1995,12: 15$ pm & $0.83 \mathrm{~m} / \mathrm{s}$ & $\operatorname{HMA}\left(17.8^{\circ} \mathrm{C}\right)$ & $15.4^{\circ} \mathrm{C}$ & $50 \mathrm{~mm}$ & $100 \%$ \\
\hline D & $2^{\text {nd }}$ Avenue, Waite Park, MN & 16 Oct. $1995,9: 30 \mathrm{pm}$ & $0.56 \mathrm{~m} / \mathrm{s}$ & $\operatorname{HMA}\left(3.1^{\circ} \mathrm{C}\right)$ & $3.8^{\circ} \mathrm{C}$ & $60 \mathrm{~mm}$ & $100 \%$ \\
\hline
\end{tabular}


Table 6. RMSE results in the comparison of calculated and measured temp.

\begin{tabular}{ccccc}
\hline \multirow{2}{*}{ Comparison } & \multicolumn{4}{c}{ Location } \\
\cline { 2 - 5 } & SITE A & SITE B & SITE C & SITE D \\
\hline Number of comparisons & 23 & 23 & 20 & 18 \\
RMSE $\left({ }^{\circ} \mathrm{C}\right)$ & 4.32 & 5.03 & 4.45 & 2.54 \\
\hline
\end{tabular}

\subsubsection{Allowable asphalt temperature at opening to traffic}

Freshly laid asphalt must be sufficiently cool, to prevent premature damage, before it can be opened to traffic. According to the FAA specification [30], the temperature of new pavement has to be below $65^{\circ} \mathrm{C}$ before it can be trafficked. A construction specification by Japan Civil Aviation Bureau (2001) [1] recommended $50^{\circ} \mathrm{C}$ as the permissible temperature. An actual runway rehabilitation in Frankfurt Airport, however, suggested that the temperature of newly laid asphalt containing polymer and Sasobit modified binder can be opened to traffic at a significantly higher temperature: $85^{\circ} \mathrm{C}$ [3]. It was reported that no visible distress was found after the new pavement was trafficked. Similarly, a laboratory test performed in this research and in a previous study [31] found acceptable deformation resistance of asphalt mixtures containing SBS polymer when tested at $75-85^{\circ} \mathrm{C}$. These findings suggest that different binders can be opened to traffic at different temperature and, thus, shoul encourage airport authorities to be more flexible with their specifications, particularly for mixtures containing PMBs. In this research, the temperature of opening to traffic of $65^{\circ} \mathrm{C}$ and $80^{\circ} \mathrm{C}$ was selected for the analysis to represent asphalt mixtures with neat binder and polymer modified binder, respectively.

\subsubsection{Comparison of cooling response of HMA and WMA}

Making use of the validated models, this section presents case studies to evaluate the cooling time needed by newly laid HMA and WMA overlay from its laying temperature to the allowable temperature at opening to traffic. The calibrated thermo-physical properties of the HMA and WMA from a previous study by Zhu, Chu [28] was adopted for the model. The study suggested a higher thermal conductivity and lower specific heat of WMA, compared to HMA, see Table 7. A typical tropical project environment locations were used for the model as the higher air temperature than many other places is likely to give a conservative estimate of cooling rate (Table 8). The empirical equation as displayed in Eq. (2) [32], was found to be suitable in calculating the heat transfer coefficient (h) in pavement surface.

$$
h=5.8+4.1 v_{w}
$$

where $h$ is Convective heat transfer coefficient and $v_{w}$ is wind speed $(\mathrm{m} / \mathrm{s})$. The input parameters for the model are shown in Table 8.
Table 7. Thermal properties of HMA and WMA for the model, adopted from Zhu, Chu [28]

\begin{tabular}{ccccc}
\hline Materials types & $\begin{array}{c}\text { Thermal } \\
\text { conductivity } \\
, k(\mathrm{~W} / \mathrm{K} . \mathrm{m})\end{array}$ & $\begin{array}{c}\text { Specific } \\
\text { heat, } C \\
(\mathrm{~W} . \mathrm{s} / \mathrm{kg} . \mathrm{K})\end{array}$ & $\begin{array}{c}\text { Density } \\
\left(\mathrm{kg} / \mathrm{m}^{3}\right)\end{array}$ & $\begin{array}{c}\text { Initial } \\
\text { temp. } \\
\left({ }^{\circ} \mathrm{C}\right)\end{array}$ \\
\hline HMA overlay & 1.89 & 800 & 2400 & 145 \\
WMA overlay & 1.31 & 950 & 2400 & varied \\
Existing asphalt & 1.89 & 800 & 2400 & 25 \\
Base-layer & 1.13 & 805 & 2200 & 22 \\
Subgrade & 1.10 & 1100 & 2100 & 21 \\
\hline
\end{tabular}

Table 8. Input of weather condition.

\begin{tabular}{cc}
\hline Input & Value \\
\hline Ambient night-time temperature & $25^{\circ} \mathrm{C}$ \\
Wind speed & $0.83 \mathrm{~m} / \mathrm{s}$ \\
heat transfer coefficients & $9.21 \mathrm{~W} / \mathrm{m} 2{ }^{\circ} \mathrm{C}$ \\
Existing surface temp. & $25^{\circ} \mathrm{C}$ \\
Solar flux & $0 \mathrm{~W} / \mathrm{m} 2$ (night) \\
\hline
\end{tabular}

Four different overlay thicknesses lift paving operations presented in Table 9 are considered to compare the cooling response of HMA and WMA. In the case of multi-lift paving operation, it is assumed that the first lift is laid and compacted. The next lift is then placed immediately after the first lift reaches $80^{\circ} \mathrm{C}$ as suggested by Corlew and Dickson (1968) [33].

Table 9. Variations of asphalt overlay thicknesses for analysis

\begin{tabular}{ccc}
\hline $\begin{array}{c}\text { Designati } \\
\text { on }\end{array}$ & $\begin{array}{c}\text { Overlay } \\
\text { thickness }\end{array}$ & Description \\
\hline T1 & $70 \mathrm{~mm}$ & Single lift \\
T2 & $100 \mathrm{~mm}$ & Single lift \\
T3 & $140 \mathrm{~mm}$ & 2 lifts. A $70 \mathrm{~mm}$ lift and $70 \mathrm{~mm}$ lift \\
T4 & $150 \mathrm{~mm}$ & 2 lifts. A $100 \mathrm{~mm}$ lift and $50 \mathrm{~mm}$ lift \\
\hline
\end{tabular}

The cooling curve of the four asphalt overlay strategies for HMA, WMA-20, and WMA-30 are presented in Fig. 15(a) to (d). Moreover, the cooling times required for all asphalt layers to cool down to $65^{\circ} \mathrm{C}$ and $80^{\circ} \mathrm{C}$ are presented in Table 10. The following observations can be drawn from the cooling results:

- For the cases studied, WMA has shorter cooling times compared to HMA. The difference in cooling periods is greater for those cases with greater overlay thickness. The time saving by using WMA made with Sasobit is given in Table 10. Using WMA with lower production temperature is presumably more effective to reduce the cooling time of newly paved asphalt.

- In general, it was observed that the use of WMA, compared to HMA, shortened the closure time of the airport during night time construction by 8-67 minutes, depending on the asphalt overlay thickness, traffic opening temperature, and WMA production temperature. When the WMA is produced at a lower temperature, the airfield closure can be further reduced. 
$70 \mathrm{~mm}$ thickness

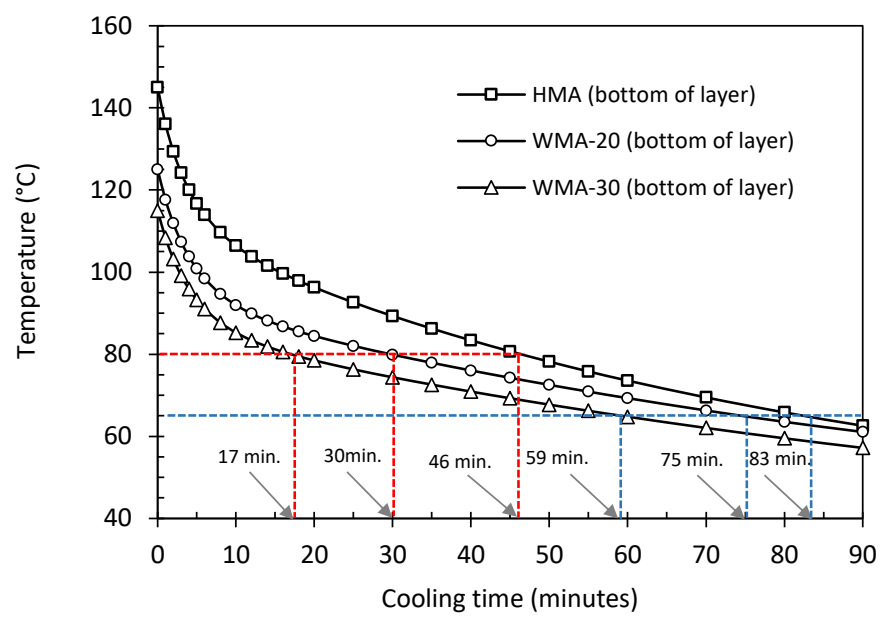

(a) Lift thickness: $70 \mathrm{~mm}$

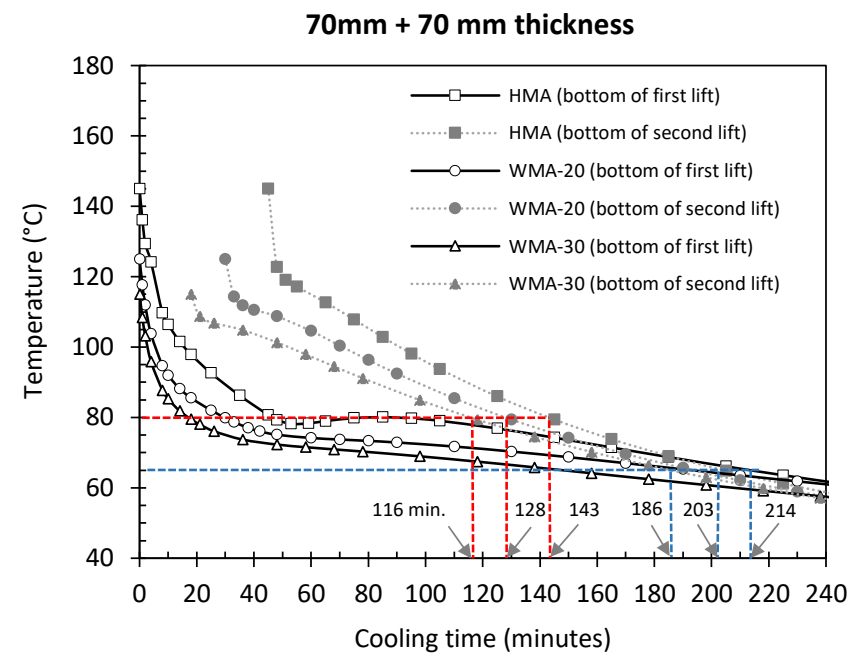

(c) Lift thickness: $70 \mathrm{~mm}+70 \mathrm{~mm}$
$100 \mathrm{~mm}$ thickness

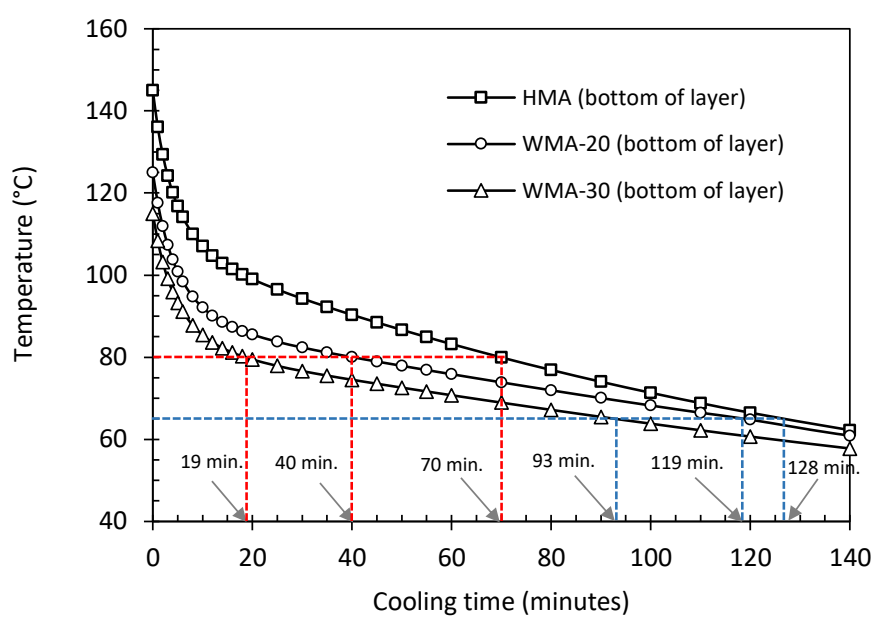

(b) Lift thickness: $100 \mathrm{~mm}$

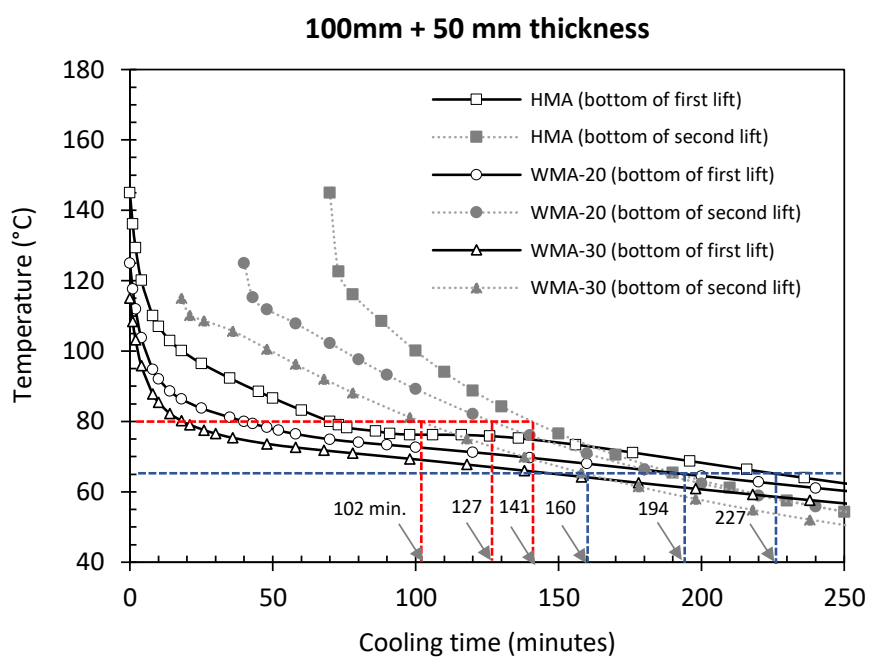

(d) Lift thickness: $100 \mathrm{~mm}+50 \mathrm{~mm}$

Fig. 15. HMA and WMA cooling curves for different overlay thickness at the bottom of layer

Table 10. HMA and WMA cooling times needed and expected of WMA time saving during night-time construction

\begin{tabular}{|c|c|c|c|c|c|c|c|c|c|c|c|}
\hline \multirow{3}{*}{$\begin{array}{l}\text { Overlay } \\
\text { Strategy }\end{array}$} & \multirow{3}{*}{$\begin{array}{l}\text { Lift } \\
\text { thickness } \\
(\mathrm{mm})\end{array}$} & \multicolumn{6}{|c|}{ Cooling time needed for asphalt mixtures to reach traffic opening temp.: } & \multicolumn{4}{|c|}{$\begin{array}{l}\text { WMA time saving (minutes), compared to HMA for } \\
\text { traffic opening temp.: }\end{array}$} \\
\hline & & \multicolumn{3}{|c|}{$65^{\circ} \mathrm{C}$} & \multicolumn{3}{|c|}{$80^{\circ} \mathrm{C}$} & \multicolumn{2}{|c|}{$65^{\circ} \mathrm{C}$} & \multicolumn{2}{|c|}{$80^{\circ} \mathrm{C}$} \\
\hline & & HMA & WMA-20 & WMA-30 & HMA & WMA-20 & WMA-30 & WMA-20 & WMA-30 & WMA-20 & WMA-30 \\
\hline $\mathrm{T} 1$ & 70 & 83 & 75 & 59 & 46 & 30 & 17 & 8 & 24 & 16 & 29 \\
\hline $\mathrm{T} 2$ & 100 & 128 & 119 & 93 & 70 & 40 & 19 & 9 & 35 & 30 & 51 \\
\hline T3 & $70+70$ & 214 & 203 & 186 & 143 & 128 & 116 & 11 & 28 & 15 & 27 \\
\hline $\mathrm{T} 4$ & $100+50$ & 227 & 194 & 160 & 141 & 127 & 102 & 33 & 67 & 14 & 39 \\
\hline
\end{tabular}

- If the critical temperature at opening to traffic is raised, further savings can be made. E.g. raising the permissible temperature from $65^{\circ} \mathrm{C}$ to $80^{\circ} \mathrm{C}$ reduces the cooling time of T1-HMA for almost 40 minutes. This result suggests that opening the new asphalt to traffic at a high temperature significantly contributes to the reduced cooling time and/or shortened airfield closure.

\subsubsection{Comparison of HMA and WMA construction time}

In the following section, a case study based on an airfield overlay project is presented to highlight WMA technologies for shortening the overall project nights/days of airfield runway rehabilitation. Four different overlay thicknesses determined earlier for cooling time analyses are used to investigate the HMA 
and WMA construction time. The time window of seven hours is assumed to be available each night for the overlay works. The runway dimension to be overlaid is taken as $3600 \times 60 \mathrm{~m}$. The construction stage and the work period of each stage are illustrated in Fig. 16, and Table 12, respectively. This construction stage is adapted from the typical asphalt overlay work in Indonesia and a real case in Fukuoka Airport, Japan [1].

The specification and construction productivity of each construction equipment is presented in Table 11. In this research, the paver productivity is set as the leading factor, whereas, the number of roller equipment needed is calculated in order to match its output with the paver output. It is also assumed that the distance paver-roller is 15 minutes.

The available time for asphalt placement and compaction for each mixture depends on the cooling time determined from the previous analysis. The typical construction schedule per night for three different asphalt mixtures (HMA, WMA-20, WMA-30) for overlay thickness of 100mm (T2) is shown in Fig. 17. It is apparent from Fig. 17 that due to the shorter cooling time, the available time for the contractor to place the asphalt is longer when the WMA is used, compared to HMA. This indicates more volume of asphalt could be paved each night by using WMA, and thus shorten the overall contract.

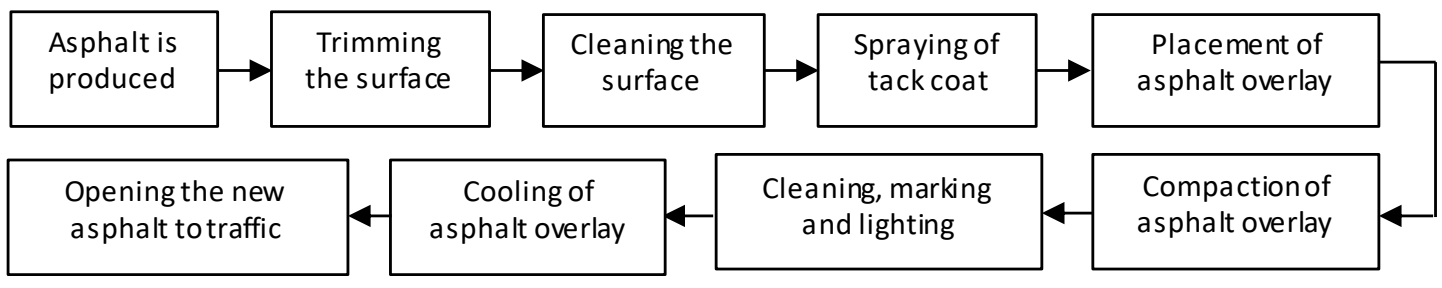

Fig. 16. Construction stage of asphalt overlay

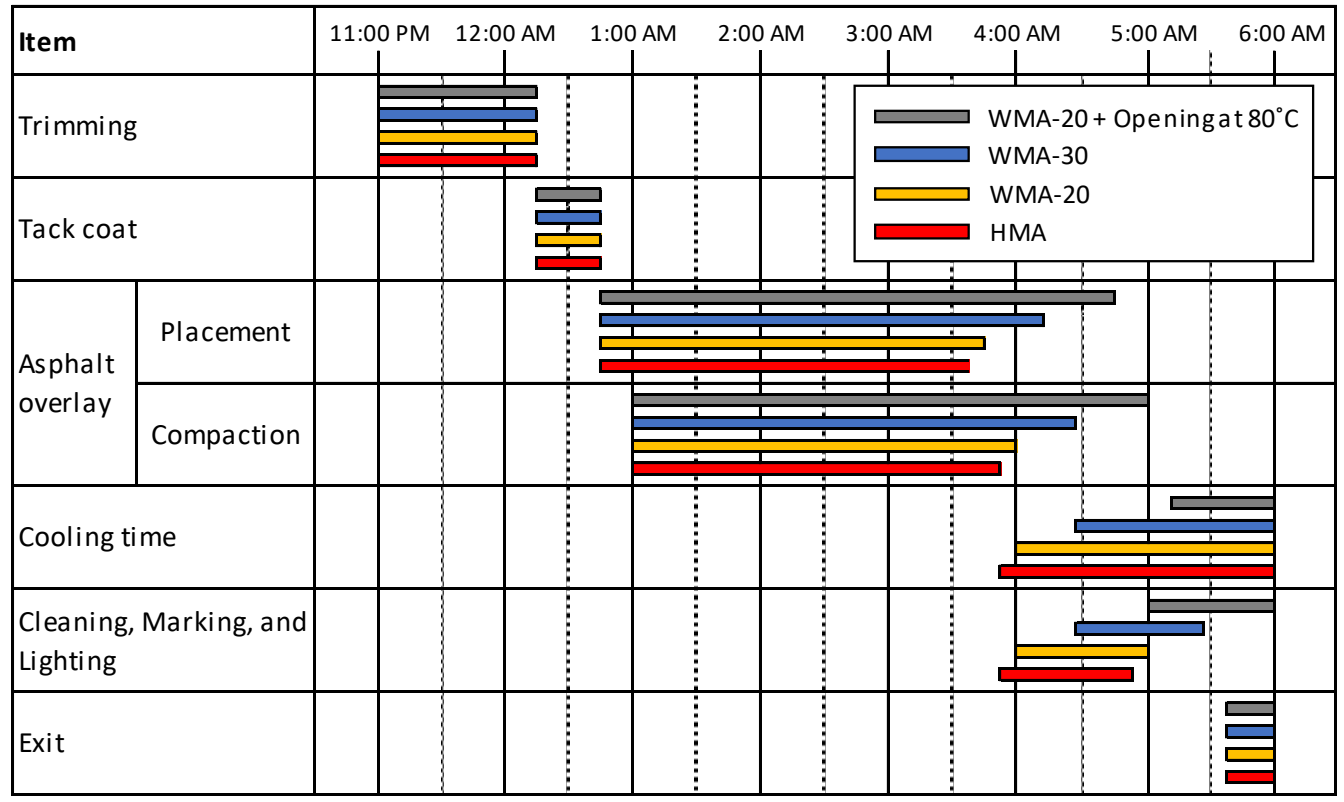

Fig. 17. Construction schedule of asphalt overlay each night (7 hours of window time) for different mixtures (100mm)

Table 11. Equipment productivity

\begin{tabular}{|c|c|c|c|c|c|c|}
\hline Equipment & Speed (m/min) & Width (m) & $\begin{array}{c}\text { Number of } \\
\text { passes }\end{array}$ & Overlap & $\begin{array}{l}\text { Number of } \\
\text { equipment }\end{array}$ & $\begin{array}{c}\text { Productivity (ton/hour) of } \\
\text { each equipment }\end{array}$ \\
\hline Asphalt paver & $2-4$ & 7.5 & - & - & 2 & 212 \\
\hline Tandem roller & 25 & 1.5 & $6-8$ & 0.25 & 8 & 37 \\
\hline Pneumatic tire roller & 45 & 2 & $6-8$ & 0.25 & 4 & 80 \\
\hline
\end{tabular}


Table 12. Work period for night-time construction for each stage

\begin{tabular}{lc}
\hline Variables & Time (minutes) \\
\hline Time for trimming the surface & 75 \\
Time for applying the tack coat & 30 \\
Time for restoring the line marking and lighting & 60 \\
\hline
\end{tabular}

Based on the available time for construction and productivity of each equipment, presented in Table 11, the volume of asphalt production each night can be calculated. The predicted overall construction period for different overlay thickness and asphalt mixtures is presented in Table 13. For illustrative purposes, Fig. 18 shows the cumulated length of runway overlay paved and expected overall construction time for an overlay thickness of $100 \mathrm{~mm}$ (T2).

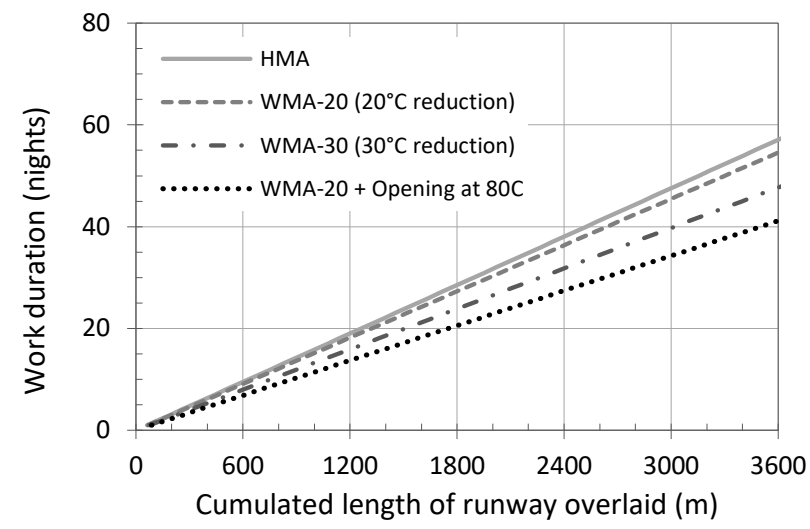

Fig. 18. Cumulated length of runway overlay paved $(m)$ and expected overall construction time (nights) for T2 HMA and WMA

As seen in Fig. 18, for an asphalt overlay with a thickness of $100 \mathrm{~mm}$ in a $3600 \mathrm{~m} \times 60 \mathrm{~m}$ runway, it is predicted that 58 nights are needed for asphalt overlay work to finish when the HMA is used, whereas 55 and 48 nights are needed when WMA-20 and WMA-30 are used, respectively. The nights needed to finish the overlay reduce to 42 nights when WMA20 is opened to traffic at a higher temperature $\left(80^{\circ} \mathrm{C}\right)$. In general, for the case studied, the use of WMA could shorten the overall project period by 2-16 nights for a single lift overlay. The reduction of asphalt overlay construction time with the use of WMA is more significant for greater lift thickness and multi-lift operation, as seen in Table $\mathbf{1 3}$.

Multi lift pavement is not recommended to obtain rapid construction and rapid opening of asphalt to traffic in the case of limited time available. This is because more nights of work to finish the projects. In the case of large overlay thickness, it is recommended that overlay is done in one lift and then continued for the next layer when the whole runway area is paved with the first layer. For instance, if the traffic opening temperature of $65^{\circ} \mathrm{C}$ is used, 35 nights are needed to finish one layer of $70 \mathrm{~mm}$, meaning that 70 nights are needed to finish two-layer of $140 \mathrm{~mm}$. In contrast, it takes 181 nights to finish the project when the multi lift operation $(70+70 \mathrm{~mm})$ is applied every night due to the slower cooling of a thick asphalt layer. However, with this strategy several drawbacks could occur, including the increase of transverse joint and the need for interface treatment and tack coating, and there are certain to be time penalties in addressing these.

The results in Table 13 also highlight the importance of selecting traffic opening temperature on reducing the number of pavement construction nights. As an illustration, it was found that 14 nights could be saved, for a $100 \mathrm{~mm}$ overlay of HMA, by raising traffic opening temperature, from $65^{\circ} \mathrm{C}$ to $80^{\circ} \mathrm{C}$. The construction time (night) saving is greater for those cases with greater overlay thickness and multi lift operation.

Overall, the findings of this study suggest that the mixtures containing polymer modified bitumen (PMB) and WMA additives could be beneficial to accelerate the airfield pavement construction. It provides double advantages: (1) shortening the cooling time of the newly laid asphalt pavement due to its lower initial temperature, and (2) enabling asphalt opening to traffic at a significantly higher temperature than existing constructions specification due to its better rutting resistance

Moreover, the opening of runway overlay to traffic does not depend only on the time of asphalt to cool but also depends on the time of restoring the lighting system and line marking at the end of each night. In the case when the time for restoring the line marking and lighting is greater than the cooling time, the use of WMA would be pointless in terms of its benefit of rapid construction. For example, it can be seen from Table 13, for $\mathrm{T} 1$, the overall project period of WMA-30 + opening at $80^{\circ} \mathrm{C}$ is the same with WMA-30 + opening at $65^{\circ} \mathrm{C}$. This is because, although the cooling time of WMA-30 $+80^{\circ} \mathrm{C}$ is 17 minutes, the assumed restoration time: 60 minutes, is used as the determining factor.

Table 13. Overall construction time HMA and WMA during night-time construction

\begin{tabular}{|c|c|c|c|c|c|c|c|c|c|c|c|}
\hline \multirow{3}{*}{$\begin{array}{l}\text { Overlay } \\
\text { Strategy }\end{array}$} & \multirow{3}{*}{$\begin{array}{l}\text { Lift } \\
\text { thickness } \\
(\mathrm{mm})\end{array}$} & \multicolumn{6}{|c|}{$\begin{array}{l}\text { Expected overall project time on a-3600 x } 60 \text { m runway overlay (nights) for } \\
\text { asphalt mixtures and different traffic opening temp.: }\end{array}$} & \multicolumn{4}{|c|}{$\begin{array}{c}\text { WMA savings (nights), compared to HMA for traffic } \\
\text { opening temp.: }\end{array}$} \\
\hline & & \multicolumn{3}{|c|}{$65^{\circ} \mathrm{C}$} & \multicolumn{3}{|c|}{$80^{\circ} \mathrm{C}$} & \multicolumn{2}{|c|}{$65^{\circ} \mathrm{C}$} & \multicolumn{2}{|c|}{$80^{\circ} \mathrm{C}$} \\
\hline & & HMA & WMA-20 & WMA-30 & HMA & WMA-20 & WMA-30 & WMA-20 & WMA-30 & WMA-20 & WMA-30 \\
\hline $\mathrm{T} 1$ & 70 & 35 & 33 & 31 & 31 & 31 & 31 & 2 & 4 & - & - \\
\hline $\mathrm{T} 2$ & 100 & 58 & 55 & 48 & 44 & 42 & 42 & 3 & 10 & 2 & 2 \\
\hline T3 & $70+70$ & 181 & 153 & 130 & 95 & 89 & 81 & 28 & 51 & 6 & 14 \\
\hline $\mathrm{T} 4$ & $100+50$ & 221 & 152 & 115 & 101 & 93 & 82 & 69 & 106 & 8 & 19 \\
\hline
\end{tabular}




\section{Summary and Conclusions}

In this study, the use of WMA in nighttime airfield rehabilitation, compared to HMA, was investigated. Two different WMA technologies (organic and chemical) were investigated through a series of laboratory tests to see the WMA rutting performance at high temperatures when the newly laid asphalt overlay is opened to traffic. Furthermore, a validated finite element (FE) solution for one-dimensional transient heat-transfer model is employed to analyze the effect of the use of WMA on shortening the cooling time and overall overlay project time.

The laboratory tests presented in this study indicate that, in the general, the WMAs have a rutting performance at high temperatures during the opening to traffic similar to, or better than HMA. It was found that, compared to HMA, WMASasobit showed excellent rutting resistance at high temperature, enabling the pavement to be opened to traffic at a higher temperature. Furthermore, the cooling analysis presented in this study showed that, in comparison to HMA, the use of WMA could shorten the closure time of airport during the night time construction by 8-67 minutes, depending on the asphalt overlay thickness, specified traffic opening temperature and WMA production temperature. The use of WMA could also reduce the overall construction period by 2-16 nights for a single lift overlay, for the cases studied which would represent a shortening of the overlay period by 4$24 \%$.

\section{Acknowledgement}

The study was made possible with funding from the LPDP (Indonesia Endowment Fund for Education), Ministry of Finance, the Republic of Indonesia. The author would like to thank LPDP for providing financial support for this research.

\section{References}

[1] Y. Hachiya, K. Su, I. Motono, T. Muranaga, A. Kajitani, T. Kano, Implementing overnight asphalt inlay work on working runway, in: Proc. 4th Eurasphalt Eurobitume Congr. , Copenhagen, Denmark, 2008.

[2] W.P. Wills, Current Practices on Nighttime Pavement Construction Asphaltic Concrete, US Department of Transportation, Federal Aviation Administration, 1982.

[3] B. Aho, D. Hein, S. Dennechuk, R. Bessom, 10 Years of Experience Using Warm Mix Asphalt for Airside Pavements-Boston Logan Airport, Int. Conf. Transp. Dev. 2016. (2016) 1-12.

[4] C.H. David, H.W. Wyllie, I. Widyatmoko, R.C. Elliott, B.K. Larsen, Planning, Design and Implementation of Major
Runway Resurfacing at Hong Kong International Airport, in: Sixth Int. Conf. Road Airf. Pavement Technol. (6th ICPT), Sapporo, Japan, 2008.

[5] G. White, Expedient runway upgrade technologies, in: A. Loizos, I. Al-Qadi, T. Scarpas (Eds.), 10th Int. Conf. Bear. Capacit. Roads, Railw. Airfields, 2017: pp. 17351741.

[6] M. Mejías-Santiago, J. Doyle, J. Rushing, Accelerated Pavement Testing of Warm-Mix Asphalt for HeavyTraffic Airfields, Transp. Res. Rec. J. Transp. Res. Board. (2014) 11-20.

[7] G. White, Warm Mix Asphalt For Australian Airports, Int. J. Pavement Eng. Asph. Technol. 16 (2015) 11-29. https://doi.org/10.1515/ijpeat-2015-0001.

[8] N. Garg, H. Kazmee, L. Ricalde, T. Parsons, Rutting Evaluation of Hot and Warm Mix Asphalt Concrete under High Aircraft Tire Pressure and Temperature at National Airport Pavement and Materials Research Center, Transp. Res. Rec. 2672 (2018) 117-127. https://doi.org/10.1177/0361198118794293.

[9] A. Jamshidi, M.O. Hamzah, Z. You, Performance of Warm Mix Asphalt containing Sasobit ${ }^{\circledR}$ : State-of-the-art, Constr. Build. Mater. 38 (2013) 530-553. https://doi.org/10.1016/j.conbuildmat.2012.08.015.

[10] FAA, Standards for specifying construction of airports, AC 150-5370-10G, (2014).

[11] J. Liu, S. Saboundjian, P. Li, B. Connor, B. Brunette, Laboratory Evaluation of Sasobit-Modified Warm-Mix Asphalt for Alaskan Conditions, J. Mater. Civ. Eng. 23 (2011) 1498-1505. https://doi.org/doi:10.1061/(ASCE)MT.19435533.0000226.

[12] N.M. Wasiuddin, S. Selvamohan, M.M. Zaman, M.L.T.A. Guegan, Comparative Laboratory Study of Sasobit and Aspha-Min Additives in Warm-Mix Asphalt, Transp. Res. Rec. 1998 (2007) 82-88. https://doi.org/10.3141/199810.

[13] Y. Tasdemir, High temperature properties of wax modified binders and asphalt mixtures, Constr. Build. Mater. 23 (2009) 3220-3224. https://doi.org/https://doi.org/10.1016/j.conbuildmat. 2009.06.010.

[14] H.M.R.D. Silva, J.R.M. Oliveira, J. Peralta, S.E. Zoorob, Optimization of warm mix asphalts using different blends of binders and synthetic paraffin wax contents, Constr. Build. Mater. 24 (2010) 1621-1631. https://doi.org/https://doi.org/10.1016/j.conbuildmat. 2010.02.030.

[15] V. Jalali, J.R.A. Grenfell, A.R. Dawson, Temperature Effect on Warm Mix Asphalt Performance, in: Y.R. Kim 
(Ed.), Nternational Conf. Asph. Pavements, CRC Press: London, 2014: p. 1966.

[16] A. Abed, N. Thom, J. Grenfell, A novel approach for rational determination of warm mix asphalt production temperatures, Constr. Build. Mater. 200 (2019) 80-93. https://doi.org/https://doi.org/10.1016/j.conbuildmat. 2018.12.082.

[17] E. Sanchez-Alonso, A. Vega-Zamanillo, D. Castro-Fresno, M. DelRio-Prat, Evaluation of compactability and mechanical properties of bituminous mixes with warm additives, Constr. Build. Mater. 25 (2011) 2304-2311. https://doi.org/https://doi.org/10.1016/j.conbuildmat. 2010.11.024.

[18] J.A. D'Angelo, The Relationship of the MSCR Test to Rutting, Road Mater. Pavement Des. 10 (2009) 61-80. https://doi.org/10.1080/14680629.2009.9690236.

[19] I.A. Syed, U.A. Mannan, R.A. Tarefder, Comparison of rut performance of asphalt concrete and binder containing warm mix additives, Int. J. Pavement Res. Technol. 12 (2019) 162-169. https://doi.org/10.1007/s42947-019-0021-4.

[20] R. Salim, A. Gundla, A. Zalghout, B.S. Underwood, K.E. Kaloush, Relationship between Asphalt Binder Parameters and Asphalt Mixture Rutting, Transp. Res. Rec. 2673 (2019) 431-446. https://doi.org/10.1177/0361198119842129.

[21] F. Morea, R. Marcozzi, G. Castaño, Rheological properties of asphalt binders with chemical tensoactive additives used in Warm Mix Asphalts (WMAs), Constr. Build. Mater. 29 (2012) 135-141. https://doi.org/https://doi.org/10.1016/j.conbuildmat. 2011.10.010.

[22] H. Ziari, R. Babagoli, Evaluation of Fatigue and Rutting Behavior of Asphalt Binder Containing Warm Additive, Pet. Sci. Technol. 33 (2015) 1627-1632. https://doi.org/10.1080/10916466.2015.1084320.

[23] A.W. Ali, H.H. Kim, M. Mazumder, M.-S. Lee, S.-J. Lee, Multiple Stress Creep Recovery (MSCR) characterization of polymer modified asphalt binder containing wax additives, Int. J. Pavement Res. Technol. (2018). https://doi.org/https://doi.org/10.1016/j.ijprt.2018.05. 001.

[24] A. Julaganti, R. Choudhary, A. Kumar, Permanent Deformation Characteristics of Warm Asphalt Binders under Reduced Aging Conditions, KSCE J. Civ. Eng. 23 (2019) 160-172. https://doi.org/10.1007/s12205-0171903-0.

[25] R. Taqia, T. Nick, D. Andrew, Strategies for Reduced Cooling Time of Asphalt for Airfield Pavement Overlay, Airf. Highw. Pavements 2019. (2020) 251-265. https://doi.org/doi:10.1061/9780784482476.026.

[26] H. Kassem, G. Chehab, G. Saad, An FEM-predictive tool for simulating the cooling characteristics of freshly paved asphalt concrete layers, Int. J. Pavement Eng. 16 (2014) 157-167. https://doi.org/10.1080/10298436.2014.937714.

[27] Y. Wang, S. Zhu, A.S.T. Wong, Cooling Time Estimation of Newly Placed Hot-Mix Asphalt Pavement in Different Weather Conditions, J. Constr. Eng. Manag. 140 (2014) 04014009. https://doi.org/10.1061/(ASCE)CO.19437862.0000832.

[28] B. Zhu, L. Chu, T.F. Fwa, Cooling characteristics of warm mix asphalt for multi-lift pavement repair and resurfacing, Int. J. Pavement Eng. (2019) 1-12. https://doi.org/10.1080/10298436.2019.1666130.

[29] B.A. Chadbourn, D. Newcomb, V. Voller, R.A. Desombre, J.A. Luoma, D.H. Timm, An asphalt paving tool for adverse conditions, 1998 .

[30] FAA, Off-Peak Construction of Airport Pavements Using Hot-Mix Asphalt: Advisory Circular 150/5370-13A, (2006) 1-4. https://doi.org/AFS-800 AC 91-97.

[31] T. Rahman, A. Dawson, N. Thom, The Permissible Temperature of Newly Laid Asphalt at Opening to Airfield Traffic, in: A.F. Nikolaides, E. Manthos (Eds.), Bitum. Mix. Pavements VII, CRC Press, Thessaloniki, Greece, 2019. https://doi.org/https://doi.org/10.1201/978135106326 5.

[32] M.R. Hall, P.K. Dehdezi, A.R. Dawson, J. Grenfell, R. Isola, Influence of the Thermophysical Properties of Pavement Materials on the Evolution of Temperature Depth Profiles in Different Climatic Regions, J. Mater. Civ. Eng. 24 (2012) 32-47. https://doi.org/10.1061/(asce)mt.1943-5533.0000357.

[33] J.S. Corlew, P.F. Dickson, Methods for calculating temperature profiles of hot-mix asphalt concrete as related to the construction of asphalt pavements, in: Assoc Asph. Paving Technol Proc, 1968. 